\title{
The ultrastructure of the thecal cell of the teleost, Oryzias latipes, during ovulation in vitro
}

\author{
Paula Pendergrass and P. Schroeder* \\ Department of Biology, Texas Woman's University, Houston Campus, 1130 M. D. Anderson, \\ Houston, Texas 77030, and *Department of Zoology, Washington State University, \\ Pullman, Washington 99163, U.S.A.
}

\begin{abstract}
Summary Ultrastructural examination of the follicular envelope of the teleost, Oryzias latipes, during ovulation in vitro showed that the follicle cell layer became increasingly dissociated. Microfilaments, measuring 50-70 $\AA$, were sparse in the thecal cells at the start of incubation, but were organized into bands after $5 \mathrm{hr}$, and into bundles after $10 \mathrm{hr}$ of incubation. It is suggested that these microfilaments are contractile and are involved in cell movement during ovulation.
\end{abstract}

\section{Introduction}

Ovulation in non-mammalian vertebrates has been consistently described as a process whereby follicular layers immediately surrounding the apex of the oocyte are dissociated, forming a rupture which is smaller in diameter than the oocyte, and through which the oocyte is squeezed (Asdell, 1962). In the fish, Oryzias latipes, the process of rupture and oocyte extrusion occurs in vitro in isolated, intact follicles under the influence of several gonadotrophins and steroids (Hirose, 1971, 1972a; Hirose \& Hirose, 1972; Hirose \& Donaldson, 1972). Since ovulation occurs from isolated follicles, it cannot be dependent on non-follicular ovarian smooth muscle, but must be associated with a mechanism(s) present within the follicular envelope itself, which consists of a layer of follicular cells, a basal lamina and several layers of thecal cells.

Previous ultrastructural studies of teleost ovarian follicles have been directed primarily towards determining the role of the follicular cells and the oocyte in the formation of the complex chorion during oogenesis (Götting, 1966; Flügel, 1967). Published illustrations of teleost thecal cells tend to be accidental inclusions in photographs of follicular cells (Yamamoto, 1963; Götting, 1965, 1966, 1967; Flügel, 1967; Busson-Mabillot, 1971; Hirose, 1972b). Apart from the endocrinological study of Nicholls \& Maple (1972), thecal cells have been rarely studied. In the present paper the ultrastructural changes in thecal cells during ovulation in vitro are described.

\section{Materials and Methods}

Fish purchased from Carolina Biological Supply Co. were kept in dechlorinated tap water at $22 \pm 1^{\circ} \mathrm{C}$ on a long-day cycle of $18 \mathrm{hr}$ light: $6 \mathrm{hr}$ dark. They were fed twice daily, once with a commercial tropical fish food (Sargent, Harrison, New Jersey) and once with frozen brine shrimp (Artemia; Delta, Harrison, New Jersey). Ovulating females were placed into individual tanks with a few males.

Ovaries from fish killed $9 \mathrm{hr}$ before first light of the daily cycle were placed into Medium-199 (M-199) (Grand Island Biological Co.) at room temperature. Oocytes with their follicular envelopes still intact were dissected out and those $\geqslant 0.8 \mathrm{~mm}$ in diameter were pooled to obtain a sufficiently large sample. The intact follicles (7-10) were placed into Petri dishes containing $5 \mathrm{ml} \mathrm{M-199.} \mathrm{Some}$ follicles were incubated in medium containing $2 \mu \mathrm{g}$ hydrocortisone acetate (Merck, Sharp and Dohme)/ml. During the incubation period of $15 \mathrm{hr}$, individual oocytes were examined for signs of 
ovulation. Some oocytes which were in the process of ovulating were placed into a drop of $\mathrm{M}-199$ on a well slide and photographed. Intact follicles were fixed for examination by transmission electron microscopy at $0,5,10$, and $15 \mathrm{hr}$ after the start of incubation.

Follicles were rinsed in cold $0 \cdot 2 \mathrm{M}$-sodium cacodylate buffer to remove M-199, then fixed for $2 \mathrm{hr}$ on ice in $1.8 \%$ glutaraldehyde in 0.1 M-sodium cacodylate buffer followed by post-fixation in $2 \%$ $\mathrm{OsO}_{4}$ in $0.1 \mathrm{M}$-sodium cacodylate buffer. The method was modified from that of Busson-Mabillot (1971); sucrose and $\mathrm{Ca}^{++}$were deleted from the fixatives because we had observed a marked reduction in the number of microfilaments in cells fixed in fluids containing these substances. Follicles were dehydrated in acetone and embedded in Epon. Silver sections were cut with a diamond knife, stained with saturated methanolic uranyl acetate and lead citrate (Reynolds, 1963), and examined with an Hitachi HS-8 electron microscope at $50 \mathrm{kV}$. An ocular micrometer calibrated against a stage micrometer was used to measure diameters of microfilaments on negatives exposed at a magnification of $\times 21,000$.

\section{Results}

\section{Light microscopy}

The increased occurrence of ovulation in vitro after addition of hydrocortisone to the medium (Hirose, 1972a) has been confirmed by our observations. The surface of the unovulated follicle is smooth and slightly opaque. Oil droplets and the long chorionic extensions (attaching filaments), which serve to attach the egg to underwater vegetation after spawning, can be seen beneath the outer layer of the follicle. On one side of the oocyte, there is an opaque area (Pl. 1, Fig. 1) apparently caused by contraction of the follicular envelope and underlying attaching filaments into a slight bulge, which can be identified in profile (P1. 1, Fig. 2). Towards the centre of this bulge, a rupture appears and spreads. As the rupture enlarges, more of the egg with the attaching filaments protrudes to become pear- and then dumb-bell-shaped (PI. 1, Figs $3 \& 4$ ). A collar of condensed follicular envelope borders the rupture and, as ovulation progresses, the rest of the follicular envelope is incorporated into this collar until the envelope eventually surrounds the base of the egg like a cap. This cap becomes detached from the egg, but remains entangled in the attaching filaments. The egg regains its spherical shape and appears as a translucent ball surrounded by attaching filaments. Our observations of ovulation in vitro correlate well with those of Robinson \& Rugh (1943): oocytes during normal ovulation are extruded free of their follicle cells, and collapsed follicles containing loosely attached follicle cells may be found in the ovaries of spawning females.

Ovulation usually occurs shortly after $10 \mathrm{hr}$ of incubation, but may occur as late as $14 \mathrm{hr}$. The total time required for the completion of ovulation in vitro after the appearance of the apical rupture varies from $1 \mathrm{~min}$ to $1 \mathrm{hr}$. Breakdown of the germinal vesicle usually occurs in ovulated oocytes, but there is no breakdown in about $5 \%$ of the eggs.

\section{Electron microscopy}

No differences were seen in the ultrastructure of follicles incubated in the presence or absence of hydrocortisone, and the following observations refer to follicles in both media. During the period of incubation, the follicular cells became more and more detached from the basal lamina and each other all around the oocyte. Before incubation only a few microfilaments were detected, usually in the inner thecal cells where desmosomes were also seen (Pl. 1, Fig. 5). After incubation for $5 \mathrm{hr}$, groups of microfilaments, $50-70 \AA$ wide, were present in longitudinal- and cross-sections of the thecal cells. The filaments were most numerous in the innermost layer of thecal cells, but some were visible in the outermost cells. There were also a few in the basal lamina, but these were only about $40 \AA$ wide.

After incubation for $10 \mathrm{hr}$ the thecal microfilaments in unovulated follicles were organized into longitudinal bundles (Pl. 2, Fig. 6). Examination of follicles which remained unovulated after $15 \mathrm{hr}$ 
PLATE 1
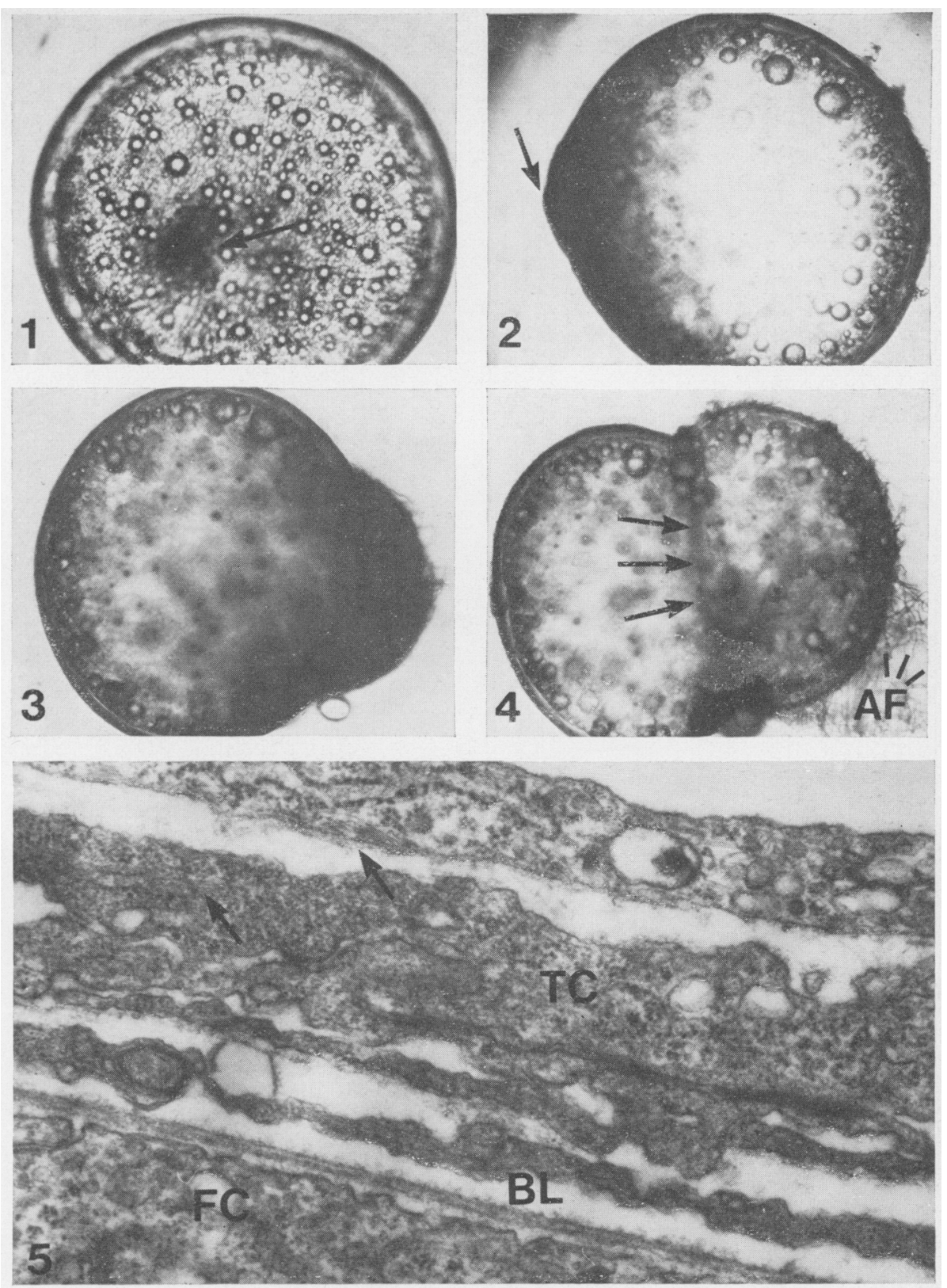

Fig. I. Unovulated follicle showing condensation of follicular envelope into future rupture site (arrow). $\times 30$.

Fig. 2. Side view of urovulated follicle showing bulge of future rupture site (arrow). $\times 30$.

Fig. 3. Partly extruded oocyte showing pear shape. $\times 30$.

Fig. 4. Dumb-bell-shaped oocyte showing collar of follicular envelope (arrows) and freed attaching filaments $(A F) \times 30$.

Fig. 5. Follicular envelope at time zero showing a few scattered microfilaments (arrows). $T C=$ thecal cell: $\mathrm{FC}=$ follicle cell: $\mathrm{BL}=$ basal lamina. $\times 44,500$. 

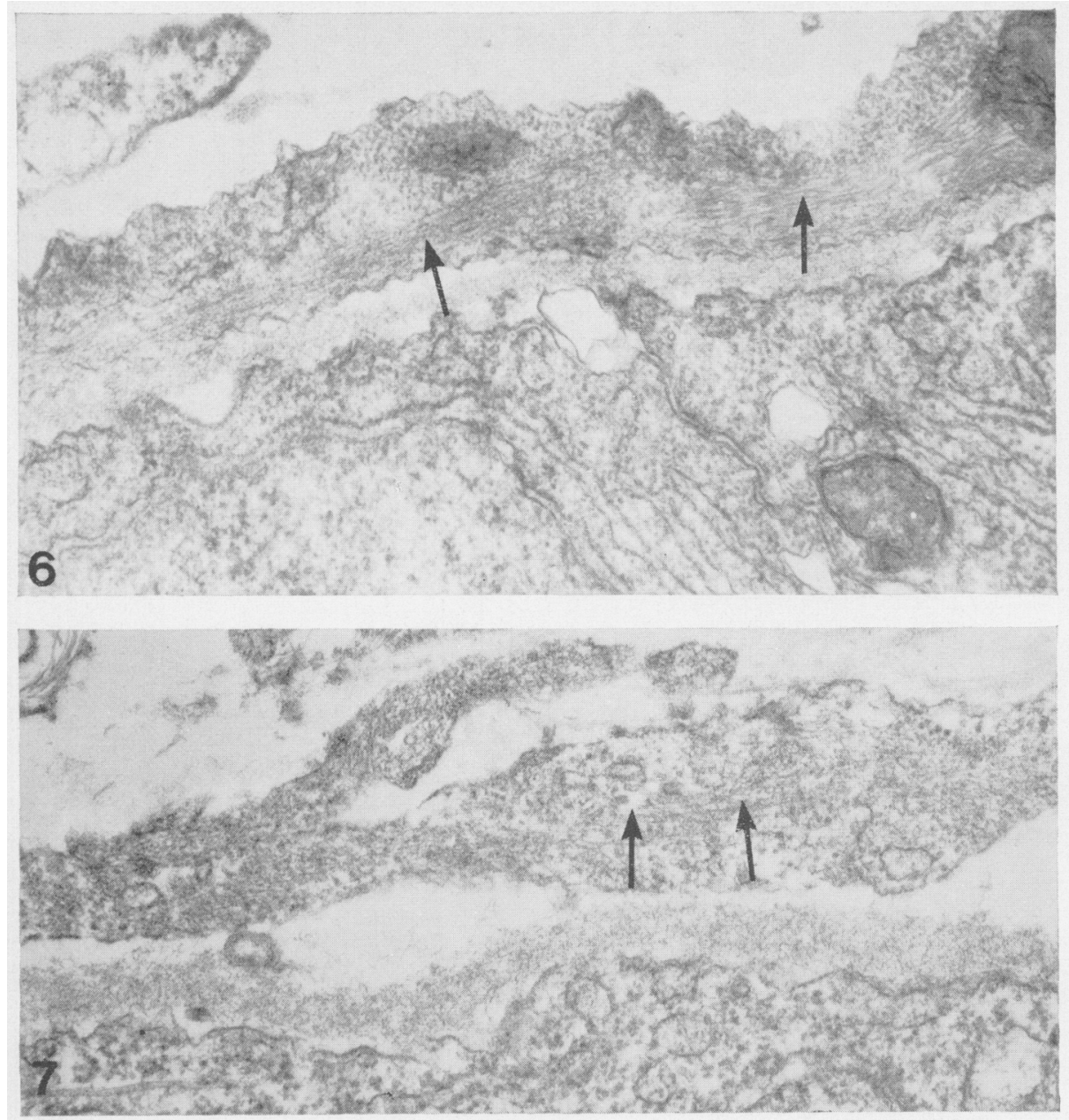

Fig. 6. Follicular envelope after incubation for $10 \mathrm{hr}$ showing bundles of microfilaments (arrows). $\times 44,500$.

Fig. 7. Thecal cells of postovulatory follicular envelope showing a band of microfilaments (arrows) lying parallel to the basal lamina. $\times 44,500$. 
revealed only a few, sparsely scattered microfilaments in the thecal layers. Myelin figures were often seen in the follicle cells at this time and were probably due to deterioration. Microfilaments were also observed lying in a plane parallel to the basement membrane within the thecal cells of the follicular envelope cap which remains intact after extrusion of the oocyte (P1. 2, Fig. 7).

\section{Discussion}

Our observations of increasing dissociation of the follicle cell layer during incubation are in close agreement with those of Yamamoto \& Yamazaki (1967) on the goldfish, although Flügel (1964) reported that the follicular cells of Salmo drew closer together preceding ovulation. The dissociation observed in Oryzias makes it unlikely that a contractile mechanism in the follicular cells could develop the force necessary to extrude the oocyte during ovulation in vitro. Contraction of isolated groups of follicle cells could result only in the shortening of individual cell groups. The mechanism for extrusion must therefore be located in the basal lamina and/or the thecal layer.

We did not detect changes in the basal lamina during ovulation in vitro although Flügel (1967) reported that in the perch (Perca fluviatilis) the basal lamina thickened from 0.4 to $2.0 \mu \mathrm{m}$ during the ovulatory period. Because of the infrequent appearance and apparently random orientation of the $40 \AA$ microfilaments in the lamina it seems unlikely that a contractile mechanism is located there.

In the thecal cells, however, 50-70 $\AA$ wide microfilaments, which are few and scattered at the start of incubation, can be seen in bands after incubation for $5 \mathrm{hr}$ and in bundles after $10 \mathrm{hr}$. In those follicles which remain unovulated after $15 \mathrm{hr}$ of incubation, relatively few filaments may be found, although filaments are present in the thecal cells of follicular envelopes which have just undergone ovulation. A contractile role has been postulated for microfilaments in other presumably nonmuscular cells (see Wessels et al., 1971), and it seems reasonable to suggest that such filaments are responsible for cell movement in Oryzias thecal cells. This interpretation is supported by the fact that ovulation in vitro in Oryzias is reversibly inhibited by cytochalasin B (P. Pendergrass, unpublished). The thecal cells are attenuated and processes of three different cells often occur one above the other in radial sections. Filaments have been observed in cell processes which are not adjacent to the basal lamina of the follicle (Pl. 1, Fig. 5), but the filament bands and bundles have always been found in juxtaposition with this lamina (Pl. 2, Fig. 6). It is possible that the basal lamina serves as a point of insertion for the filament-bearing membrane of the thecal cell, as in smooth muscle (Gabella, 1973).

Ovulation in non-mammalian vertebrates has been consistently described as a process of squeezing the oocyte through a rupture in the surrounding tissue. In the hellbender, Cryptobranchus (Smith, 1916), the frog, Rana (Rugh, 1935), and the fish, Oryzias (Robinson \& Rugh, 1943), the oocyte is constricted at the point of exit so that it is temporarily shaped like a dumb-bell. In the pigeon (Bartelmez, 1912) and the domestic fowl (Phillips \& Warren, 1937) the oocyte is squeezed through a rupture about one-half its diameter.

One of the major theories attempting to account for vertebrate ovulation in general is that contraction of ovarian smooth muscle results in rupture and ovulation, yet in animals such as the frog, Rana (Rugh, 1935), and the fish, Oryzias (Robinson \& Rugh, 1943), spontaneous ovarian contraction does not result in ovulation, and furthermore ovulation can occur after follicles have been removed from ovaries.

Attempts to induce ovulation by stimulating smooth muscle contraction or by applying direct physical pressure to follicles have been unsuccessful in the frog (Rugh, 1935) and hen (Phillips \& Warren, 1937). Kraus (1947) could not stimulate ovulation in frogs, hens and rabbits by smooth muscle stimulants or electrical shock.

There is some doubt whether smooth muscle is actually present in the ovarian follicles of nonmammalian vertebrates. Direct observation of electronmicrographs of follicles does not reveal any smooth muscle fibres. Anderson \& Yatvin (1970) pointed out that the absence of smooth muscle 
in a variety of amphibians raised the question of the source of the squeezing phenomenon accompanying ovulation.

There is an increasing amount of literature demonstrating the presence of smooth muscle or smooth muscle-like fibres in mammalian follicles (Burden, 1971, 1973; Fumagalli, Motta \& Calvieri, 1971; McReynolds, Siraki, Branson \& Polloch, 1973), but there is controversy whether such fibres are present in sufficient numbers and in the correct location to effect ovulation. While the thecal cells and microfilaments of Oryzias appear similar to the smooth muscle-like cells and fibres reported in the theca of the mammalian follicle (Osvaldo-Decima, 1970; O'Shea, 1971; Fumagalli et al., 1971; Burden, 1972, 1973; Bjersing \& Cajander, 1974), structures characteristic of smooth muscle, i.e. 'caveolae', dense patches in the filament mass, and attachment plaques (Gabella, 1973), have not been observed in the filament-containing cells of the Oryzias follicle.

Our observations suggest a preovulatory period of morphogenesis in the follicle of the teleost ovary during which cells containing an organized contractile system appear in tissue which only hours previously had contained no such cells. The lack of evidence for a role for smooth muscle in ovulation suggests that a similar system is involved in oocyte extrusion in other non-mammalian vertebrates because descriptions of ovulation are strikingly similar.

Most of this research was undertaken as partial fulfilment of the requirements for the Ph.D degree from Washington State University. The research was supported by the Electron Microscope Center at Washington State University, by NIH grant HD07194, by a grant-in-aid to research from the Society of Sigma Xi, and by departmental research funds from Texas Woman's University. The electron microscope research facilities provided by Dr Wallis Clark and Dr Luther Franklin at the University of Houston, Texas, are gratefully acknowledged.

\section{References}

Anderson, J. \& Yatvin, M. (1970) Metabolic and ultrastructural changes in the frog ovarian follicle in response to pituitary stimulation. J. Cell Biol. 47, 491-504.

AsDell, S. (1962) Mechanism of ovulation. In The Ovary, pp. 436-449. Ed. S. Zuckerman. Academic Press, New York.

Bartelmez, G. (1912) The bilaterality of the pigeon's egg. I. A study of egg organization from the first growth period of the oocyte to the beginning of cleavage. J. Morph. 23, 269-329.

Bjersing, L. \& Cajander, S. (1974) Ovulation and the mechanism of follicle rupture. V. Ultrastructure of tunica albuginea and theca externa of rabbit Graafian follicles prior to induced ovulation. Cell Tiss. Res. 153, 15-30.

Burden, H. (1971) Histochemical and electron microscope studies of the theca externa in the guinea pig. Anat. Rec. 169, 286.

BuRdEN, H. (1972) Ultrastructural observations on ovarian perifollicular smooth muscle in the cat, guinea pig, and rabbit. Am. J. Anat. 133, 125-142.

Burden, H. (1973) The distribution of smooth muscle in the cat ovary with a note on its adrenergic innervation. $J$. Morph. 140, 467-476.

Busson-Mabillor, S. (1971) Influence de la fixation chimique sur les uitrastructures. I. Etucle sur les organites de follicule ovarien d'un poisson téléostéen. J. Microscop., Paris 12, 317-348.

FlüGEL, H. (1964) Electron microscope investigation of the fine structure of the follicular cells and the zona radiata of trout oocytes during and after ovulation. Naturwissenschaften 51, 564-565.

FLÜGEL,H. (1967) Licht- und elektronenmikroskopische Untersuchungen an Oozyten und Eiern einigen Knockenfische. Z. Zellforsch. mikrosk. Anat. 83, 82-116.

Fumagalli, Z., Motta, P. \& Calvieri, S. (1971) The presence of smooth muscular cells in the ovary of several mammals as seen under the electron microscope. Experientia 27, 682-683.

Gabella, G. (1973) Fine structure of smooth muscle. Phil. Trans. Roy. Soc. 265B, 7-16.

GörrıNG, K. (1965) Die Feinstruktur der Hullschichten reifender Oocyten von Agonus cataphractus $\mathrm{L}$. (Teleostei, Agonidae). Z. Zellforsch. mikrosk. Anat. 66, 405-415.

GöTring, K. (1966) Zur Feinstruktur der Oozyten mariner Teleosteer. Helgoländer wiss. Meeresunters. 13, 118-170.

GöTtING, K. (1967) Der Follikel und die peripheren Strukturen der Oocyten der Teleosteer und Amphibien. Eine vergleichende Betrachtung auf der Grundlage elektronenmikroskopischer Untersuchungen. Z. Zellforsch. mikrosk. Anat. 79, 481-491.

HIROSE, K. (1971) Biological study on ovulation in vitro of fish. I. Effects of pituitary and chorionic gonadotropins on ovulation in vitro of Medaka, Oryzias latipes. Bull. Jap. Soc. scient. Fish. 37, 585-591. 
Hirose, K. (1972a) Biological study on ovulation in vitro of fish-IV. Induction of in vitro ovulation in Oryzias latipes oocytes using steroids. Bull. Jap. Soc. scient. Fish. 38, 457-461.

Hirose, K. (1972b) The ultrastructure of the ovarian follicle of Medaka, Oryzias latipes, Z. Zellforsch. mikrosk. Anat. 123, 316-329.

Hirose, K. \& Donaldson, E. (1972) Biological study on ovulation in vitro of fish. III. The induction of in vitro ovulation of Oryzias latipes oocytes using salmon pituitary gonadotropin. Bull. Jap. Soc. scient. Fish. 38, 97-100.

Hirose, K. \& Hirose, H. (1972) Biological study on ovulation in vitro of fish. II. Differences of ovulation rates in Oryzias latipes at the various starting hours of incubation. Bull. Jap. Soc. scient. Fish. 38, 33-42.

Kraus, S. (1947) Observations on the mechanism of ovulation in the frog, hen and rabbit. Western $J$. Surg. 55, 424-437.

McReynolds, H., Siraki, C., Branson, P. \& Polloch, R. (1973) Smooth muscle-like cells in ovaries of the hamster and gerbil. Z. Zellforsch. mikrosk. Anat. 410, 1-6.

Nicholis, T. \& MAPLE, G. (1972) Ultrastructural observations on possible sites of steroid biosynthesis in the ovarian follicular epithelium of two species of cichlid fish, Cichlasoma nigrofasciatum and Haplochromis multicolor. Z. Zellforsch. mikrosk. Anat. 128, 317-335.

O'SHEA, J. (1971) Smooth muscle-like cells in the theca externa of ovarian follicles in the sheep. $J$. Reprod. Fert. 24, 283-285.

Osvaldo-Decima, L. (1970) Smooth muscle in the ovary of the rat and monkey. J. Ultrastruct. Res. 29, 218-237.

Phillips, R. \& WARren, D. (1937) Observations concerning the mechanism of ovulation in the fowl. J. exp. Zool. 76, 117-136.

Reynolds, E. (1963) The use of lead citrate at high $\mathrm{pH}$ as an electron opaque stain in electron microscopy. J. Cell Biol. 17, 208-212.

Robinson, E. \& Rugh, R. (1943) The reproductive process of the fish, Oryzias latipes. Biol. Bull. mar. Biol. Lab., Woods Hole 84, 115-125.

Rugh, R. (1935) Ovulation in the frog. II. Follicular rupture to fertilization. $J$. exp. Zool. 71, 163193.

SMITH, B. (1916) The process of ovulation in the amphibia. Rep. Mich. Acad. Sci. 18, 102-105.

Wessels, N., Spooner, B., Ash, F., Bradley, M., Luduena, M., Taylor, E., WrenN, J. \& Yamada, K. (1971) Microfilaments in cellular and developmental processes. Science, N.Y. 171, 135-143.

Yamamoto, K. \& YAMAZAKI, F. (1967) Hormonal control of ovulation and spawning in goldfish. Gunma Symp. Endocr. 4, 121-145.

Yамамото, M. (1963) Electron microscopy of fish development. II. Oocyte-follicle cell relationship and formation of chorion in Oryzias latipes. $J$. Fac. Sci. Tokyo Univ. Sect. 4, 10, 123-127.

Received 22 October 1975 